\title{
THE EFFECT OF RELATIONSHIP MARKETING, EXPERENTIAL MARKETING AND SHARIA MARKETING CHARACTERISTICS ON CUSTOMER LOYALTY OF SHARIA BANK WITH CUSTOMER SATISFACTION AS INTERVENING VARIABLE
}

\author{
Maulana Agung Priantoro', Fetria Eka Yudiana ${ }^{2}$ \\ 1,2Institut Agama Islam Negeri Salatiga, Salatiga \\ $\bowtie$ maulanaagung1107@gmail.com¹, Fetria_belsa@yahoo.com²
}

\begin{abstract}
: Loyalty is a consumer's commitment to a business model that can be in the form of a brand, store, and/or supplier due to several things that cause consumers to make long-term purchases. The data was obtained from the distribution of questionnaires by researchers to respondents. Samples were taken as many as 100 respondents. Data collection techniques by nonprobability sampling. The data obtained were then processed using the SPSS20 tool. This research uses quantitative research by using multiple linear regression analysis and path analysis.. The results of this study indicate that the Relationship Marketing variable has a negative and insignificant effect on Loyalty. The Experiential Marketing variable has a positive and insignificant effect on Loyalty, the Characteristics Variable of Sharia Marketing has a positive and significant effect on Loyalty. Then the Satisfaction variable has a positive and insignificant effect on Loyalty. Furthermore, the Relationship Marketing variable has a positive and significant effect on satisfaction. Furthermore, the Experiential Marketing variable has a positive and significant effect on Satisfaction, the Characteristics Variable of Sharia Marketing has a positive and insignificant effect on Satisfaction, Furthermore, Satisfaction is not able to mediate the influence of Relationship Marketing on Loyalty, the Satisfaction Variable can mediate the influence of Experiential Marketing on Loyalty, and the last variable Satisfaction is able to mediate the influence of the characteristics of Sharia Marketing on Loyalty.

Keywords : Relationship Marketing, Experiential Marketing, Characteristics of Sharia Marketing, Loyalty, Satisfaction, Intervening
\end{abstract}

\section{INTRODUCTION}

Islamic banks are a form of modernization of their original institutions, namely conventional banks. In its existence, it is undeniable that Islamic banks have not been able to beat the existence of conventional banks, especially in Indonesia. To build public interest in using Islamic bank products is not easy, because people have different backgrounds and views in understanding Islamic banks. There are several factors that play an important role that the author wants to describe in the final results before and after a customer uses Islamic bank services including marketing relationships with many people, marketing experience, customer loyalty and customer satisfaction.

The development of banking in Indonesia recorded an increase in the 0JK SPS record in January 2021. This can be seen from the development of the number of assets owned, the expansion of the branch office area, the increasing number of customers, the comparison of the financial ratios of sharia business 
units (UUS) from 2018-2021 more increasing. Improvements like these make researchers believe in the importance of doing this research (ojk.go.id).

Indonesia is a country with a Muslim majority population, but it can be seen that the banking system in Indonesia still applies a lot of conventional banking systems. This can be seen also in the City of Salatiga which was recorded in 2019 the population of the city of Salatiga amounted to 195,010 people with a percentage of $78.10 \%$ being Muslim, but the use of Islamic banks in Salatiga is still very minimal, although in recent years data on the use of Islamic banks has increased ( wikipedia.org). This can be proven by officially announcing that the Mayor of Salatiga has just inaugurated the legal entity form of Perumda BPR Bank Salatiga (conventional) on January 26, 2021 by targeting 4000 customers in 2021, which is also recorded until the end of December 2020 customers of Perumda BPR Bank Salatiga has received 1911 customers with 600 of them working as civil servants (Salatiga.go.id).

Percentage of Religion in Salatiga Community

\begin{tabular}{l|c}
\hline \multicolumn{1}{c|}{ Religion } & Percentage \\
\hline Islam & $78,10 \%$ \\
\hline Christian Protestan & $21,40 \%$ \\
\hline Catholic & $5,10 \%$ \\
\hline Buddha & $0,40 \%$ \\
\hline Hindu & $0,10 \%$
\end{tabular}

Source : https://id.m.wikipedia.org/wiki/Kota_Salatiga

It can be seen from the data table above shows that the religious percentage of the majority of the population of Salatiga city is Muslim, but the use of Islamic banking services in the city of Salatiga is still very minimal as seen from the number of customers in each bank in Salatiga where there are still many people who choose to do financing or credit in conventional banking and leasing. This can also be proven by the decreasing level of customer loyalty that already exists in the banking sector of Salatiga and its surroundings. As can be seen in the decline in the predicate obtained by Islamic banking in the 2020 and 2021 Sharia Finance Institution Awards (bankjateng.co.id). Wiyanto's research (2016) shows that loyalty will tend to decrease if there is no form of empathy in a company, especially banking. This is coupled with the government's lack of attention to banking issues, especially Islamic banking, so that although the percentage of Muslims is very high in the city of Salatiga, it does not guarantee a large number of Islamic banking customers. This is why it is important to conduct this research so that it can be seen what things can meet customer needs so that the level of use of Islamic banking services will increase.

In this case the direct marketing relationship process will be tested, other circumstances state that a marketing will need the experience or ability of the marketer to market a product. Therefore, the experience of a marketer or customer using the product will greatly affect how satisfied the customer is in using the product and customer loyalty as the final output. According to Putri \& Nursinta, (2017) the significant positive influence of Relationship Marketing on loyalty. Just like Khotimah, Suharyono, and Hidayat who also concluded the same thing with Siska and Lili.

According to Karim et al., (2020) stated that the influence of the Relationship Marketing variables was negative but not significant on loyalty. 
According to Fatmawati \& Rahayu, (2018) which states that Experiential marketing consists of sense, feel, act, relate has a positive and significant effect on loyalty, while the think variable has a significant negative effect on loyalty. In contrast to the conclusion from Karuniatama et al., (2020) concluded that the effect of experiential marketing was positive but not significant on loyalty. According to Panjaitan, (2017) Research conducted states that Experiential Marketing has a positive and significant effect on loyalty. Similar to Panjaitan's research, the results are the same as the research conducted by Manengkey et al., (2019) which states that the effect of experiential marketing is also significant positive on loyalty. In this point it can be stated that there are still many uncertainties in the results of the research which explains the importance of this research being carried out to complement the sources of research literacy on the above theme.

\section{THEORY AND METHOD}

\subsection{Sosial Exchange}

Social exchange can be interpreted as a process of social exchange that occurs in human life. This exchange can be in the form of actions that can be observed from the elements of rewards, sacrifices, and benefits that mutually influence the ongoing relationship between humans. There are several substantive statements of proportion to explain the importance of human social exchange in building social relationships including; the proportion of success, stimulus, value (deprivation-satiation), and approval-aggression (approvalaggression). By understanding these proportions, the process of social exchange will be created properly, in relation to the world of work and social life of the community. (George: 1958)

\subsection{Relationship Marketing}

According to Chan (2003:6) Relationship marketing is an effort that is able to create communication between two parties by managing a symbiotic mutualism model between customers and the company. In other words, Relationship marketing can also be interpreted as an effort or effort by a company to establish short or long-term relationships, where the relationship can benefit both parties. According to Zeithaml in Alma (2007:271), Relationship Marketing is a philosophy of running a business that focuses on improving service to existing customers, rather than finding new customers. Relationship marketing emphasizes cooperation rather than competition and conflict among marketers. This concept is based on the formation of value between the company and the parties with an interest in the company.

Because of the importance of Relationship Marketing so as to create bonds/relationships between customers and companies that are able to bind old customers for long-term relationships, this theory raises two types of relations, namely relationships with companies and their marketers. Many cases occur where the bond in question is the bond between the customer and the marketer, not the company, especially the banking sector, so that in this case, many customers also switch to using other companies as marketers move to other companies. The marketer in question is an employee of the marketing department in a company. 


\subsection{Experiential Marketing}

According to the Experiential language, marketing comes from two syllables, experience and marketing. Experience means that experience is defined as a personal event that occurs due to other determining factors. Experience can also be interpreted as a subjective part in the construction of a person, in the deepening of emotions and senses directly in an event at the expense of the cognitive dimension. (Grundey, 2008:138). While marketing is an activity for management and achievement in the process of fulfilling consumer needs through the transaction process. Marketing is a social and managerial process so that individuals and/or groups can obtain their needs and wants through creation and exchange with others. Kotler and Keller, (2006: 6)

Experiential marketing is a marketing science that refers to personal events that occur, both rationally and emotionally, due to certain factors that can take the form of outside stimuli that form a mindset and have an impact on a person's behavior in the future. (Schmitt \& Simonson, 1997) An important point in experiential marketing is the processing of flavors where every customer reaction to a product/service can ultimately be responded to appropriately so that if an unwanted event occurs, it can still be handled before the news reaches the customer or other people.

\subsection{Characteristics of Sharia Marketing}

Characteristics is a marketing process that uses social elements in the process of capturing consumer behavior so that it can be easily noticed. Then sharia marketing is marketing that leads to the process of creating, offering, and changing value which in the whole process is in accordance with the principles of muamalat (business) in Islam. According to Kartajaya \& Sula, (2006) sharia marketing is a strategic business discipline that directs the process of creating, offering, and changing value from one initiator to stakeholders who in each marketing process are within the scope of Islamic principles. In the case that occurs in the marketing field, this will be very effective when it is aimed at respondents aged more than 30 years with a strong level of religiosity stability.

\subsection{Loyalty Customer}

Loyalty according to Tjiptono (2000:110) is a consumer's commitment to a business model that can take the form of a brand, store, and/or supplier due to several things that cause consumers to make purchases in the long term. In other words, customer loyalty can be seen when customers show buying behavior in a focused and continuous manner so that there is no longer any bad prejudice about a product or service being used. Loyalty can also be interpreted as conspicuous behavior of a customer after feeling his needs and desires can be fulfilled so as to create an inner attachment to carry out transactions continuously whose output is in the form of recommending goods and services to others. According to Fetria (2016:103) Loyalty can also be interpreted as a fundamental commitment to repurchase or continuously a product and/or service in the future, faithfully/loyally to buy the same product continuously. This can be seen by what customers' routines are like in making continuous purchases of products and/or services. 


\subsection{Customer Satisfactiom}

According to Tjiptono in Prihanti, (2019)Customer satisfaction is an individual's feeling after using a product and comparing performance (results) with their expectations. In this growing era, one of the processes to get loyal customers is to meet consumer needs continuously from time to time. There are also many ways that companies can do in the process of meeting consumer needs, one of which is through social analysis first so that each product can be adapted to market needs. Basically, the fulfillment of this need is carried out for the sake of the company's sustainability so that it tends to be more able to survive in any changes in economic conditions. Customer satisfaction is a condition where consumer needs can be met by the product. Kotler \& Armstrong in Dewi et al., (2015)

\subsection{Research Methods}

This research is a quantitative research, where the data used is primary data obtained from Salatiga community respondents. The population in this study is the people of the city of Salatiga who are customers of Islamic banks. The sampling method in this study is the Non Probability Sampling technique which specifically uses Accidental Sampling by distributing electronic questionnaires in the form of a Google form to random or detailed communities to WhatsApp groups of students and participants of Islamic studies that allow Islamic bank customers in the city of Salatiga. So that there are 100 respondents from Islamic bank customers in Salatiga who pass the criteria for valid and reliable answers, then proceed with classical assumption tests (normality, autocorrelation, multicollinearity), statistical tests (coefficient of determination R2, statistical test $\mathrm{F}$, statistical test $\mathrm{T}$, and The last is the path analysis test which can be concluded that the magnitude of the influence of the intervening variable in mediating the influence of the independent variable on the dependent variable in this study is Islamic banking customer loyalty.

\subsection{Hipotesis}

In this study, the authors make hypotheses that are estimated from various sources as follows:

\begin{tabular}{l|l}
\hline & \multicolumn{1}{|c}{ Description } \\
\hline H 1 & $\begin{array}{l}\text { It is suspected that Relationship marketing has a significant } \\
\text { positive effect on customer loyalty }\end{array}$ \\
\hline H 2 & $\begin{array}{l}\text { It is suspected that Experiential marketing has a significant } \\
\text { positive effect on customer loyalty }\end{array}$ \\
\hline H 3 & $\begin{array}{l}\text { It is suspected that the characteristics of sharia marketing have a } \\
\text { positive and significant influence on customer loyalty }\end{array}$ \\
\hline H 4 & $\begin{array}{l}\text { It is suspected that customer satisfaction has a significant influence } \\
\text { on customer loyalty }\end{array}$ \\
\hline H 5 & $\begin{array}{l}\text { It is suspected that Relationship marketing has a significant } \\
\text { positive effect on customer satisfaction }\end{array}$
\end{tabular}




\begin{tabular}{l|l} 
H 6 & $\begin{array}{l}\text { It is suspected that Experiential marketing has a significant } \\
\text { influence on customer satisfaction }\end{array}$ \\
\hline H 7 & $\begin{array}{l}\text { It is suspected that the characteristics of sharia marketing have a } \\
\text { positive and significant influence on customer satisfaction }\end{array}$ \\
\hline H 8 & $\begin{array}{l}\text { It is suspected that Relationship marketing has an effect on Loyalty } \\
\text { through Satisfaction as an intervening variable }\end{array}$ \\
\hline H 9 & $\begin{array}{l}\text { It is suspected that Experiential marketing has an effect on Loyalty } \\
\text { through Satisfaction as an intervening variable }\end{array}$ \\
\hline H 10 & $\begin{array}{l}\text { It is suspected that the characteristics of sharia marketing affect } \\
\text { Loyalty through Satisfaction as an intervening variable }\end{array}$
\end{tabular}

\section{RESULTS AND DISCUSSION}

\subsection{Results of data analysis}

The object of this research is Islamic banking customers in the city of Salatiga which of course is divided into various kinds of customers from various banking companies, where data analysis is carried out to examine the magnitude of the influence of the independent variables (Relationship Marketing, Experiential marketing, and Characteristics of Sharia marketing) affecting the dependent variable, namely Customer loyalty, as well as the magnitude of the influence of the intervening variable. Customer Satisfaction mediates the influence of the two between the independent variables on the dependent variable.

\section{Descriptive Statistics}

\begin{tabular}{|c|c|c|c|c|c|c|}
\hline & $\begin{array}{c}\text { Relationsh } \\
\text { ip_Marketi } \\
\text { ng } \\
\end{array}$ & $\begin{array}{c}\text { Experenti } \\
\text { al_Marke } \\
\text { ting } \\
\end{array}$ & $\begin{array}{c}\text { Karakteristik } \\
\text { _Syariah_Mar } \\
\text { keting }\end{array}$ & $\begin{array}{c}\text { Loyalita } \\
\text { s_Nasab } \\
\text { ah }\end{array}$ & $\begin{array}{c}\text { Kepuas } \\
\text { an_Nasa } \\
\text { bah }\end{array}$ \\
\hline \multirow{2}{*}{$\mathrm{N}$} & Valid & 100 & 100 & 100 & 100 & 100 \\
\hline & Missing & 0 & 0 & 0 & 0 & 0 \\
\hline \multicolumn{2}{|c|}{ Mean } & 23,4300 & 40,5000 & 32,5000 & 24,2900 & 24,0600 \\
\hline \multicolumn{2}{|c|}{ Median } & 24,0000 & 41,0000 & 33,0000 & 25,0000 & 25,0000 \\
\hline \multicolumn{2}{|c|}{ Mode } & 27,00 & 42,00 & 32,00 & 25,00 & 25,00 \\
\hline \multicolumn{2}{|c|}{ Std. Deviation } & 4,02581 & 5,42069 & 5,22330 & 3,61337 & 3,38690 \\
\hline \multicolumn{2}{|c|}{ Skewness } &,- 921 &,- 633 &,- 852 &,- 662 &,- 783 \\
\hline \multicolumn{2}{|c|}{$\begin{array}{l}\text { Std. Error of } \\
\text { Skewness }\end{array}$} & , 241 & ,241 & 241 & ,241 & ,241 \\
\hline \multicolumn{2}{|c|}{ Kurtosis } & ,640 & ,085 & ,800 &, 223 & ,292 \\
\hline \multicolumn{2}{|c|}{$\begin{array}{l}\text { Std. Error of } \\
\text { Kurtosis }\end{array}$} & ,478 & ,478 & ,478 & ,478 & ,478 \\
\hline \multicolumn{2}{|c|}{ Minimum } & 10,00 & 25,00 & 15,00 & 14,00 & 14,00 \\
\hline \multicolumn{2}{|c|}{ Maximum } & 30,00 & 50,00 & 40,00 & 30,00 & 30,00 \\
\hline \multicolumn{2}{|c|}{ Sum } & 2343,00 & 4050,00 & 3250,00 & 2429,00 & 2406,00 \\
\hline
\end{tabular}

From the results above, it can be seen that the highest mean value is owned by the experiential marketing variable of 40,5000 , while the lowest mean value is 
owned by the Relationship marketing variable of 23,4300 , then the highest median value is owned by the experiential marketing variable, which is 41,0000 , while The lowest median value is owned by the Relationship marketing variable, which is 24,000 . Then for other test results can be seen in the table above.

Tabel 1. Coefficients Variabel X1,X2,X3,Z to Y

\begin{tabular}{|c|c|c|c|c|c|c|c|c|}
\hline \multirow{2}{*}{\multicolumn{2}{|c|}{ Model }} & \multicolumn{2}{|c|}{$\begin{array}{l}\text { Unstandardized } \\
\text { Coefficient }\end{array}$} & \multirow{2}{*}{\begin{tabular}{|c|}
$\begin{array}{c}\text { Standardiz } \\
\text { ed } \\
\text { Coefficient }\end{array}$ \\
Beta \\
\end{tabular}} & \multirow[t]{2}{*}{$\mathrm{T}$} & \multirow[t]{2}{*}{ Sig. } & \multicolumn{2}{|c|}{$\begin{array}{l}\text { Collinearity } \\
\text { Statistic }\end{array}$} \\
\hline & & $\mathrm{B}$ & Std. Error & & & & Tolerance & VIF \\
\hline \multirow{5}{*}{1} & (Constant) & 2,943 & 1,496 & & 1,967 & 052 & & \\
\hline & $\begin{array}{l}\text { Relationship_Mark } \\
\text { eting }\end{array}$ &,- 048 & 104 &,- 054 &,- 463 & ,644 & ,212 & 4,707 \\
\hline & $\begin{array}{l}\text { Experential_Marke } \\
\text { ting }\end{array}$ & 173 & 103 & ,259 & 1,682 & ,096 & , 120 & 8,299 \\
\hline & $\begin{array}{l}\text { Karakteristik_Syari } \\
\text { ah_Marketing }\end{array}$ & ,386 & ,078 & ,558 & 4,968 & ,000 & ,226 & 4,419 \\
\hline & Kepuasan_Nasabah & ,122 & 163 & ,114 & ,745 & ,458 & 122, & 8,196 \\
\hline
\end{tabular}

a. Dependent Variable : Customer_Loyalty

Source: Data processed by researchers, 2021

Based on the table above, it is known that the Relationship marketing variable has an insignificant negative effect, the Experiential marketing variable, and customer satisfaction have a positive and insignificant effect, while the Characteristics of sharia marketing variable has a positive and significant effect on customer loyalty.

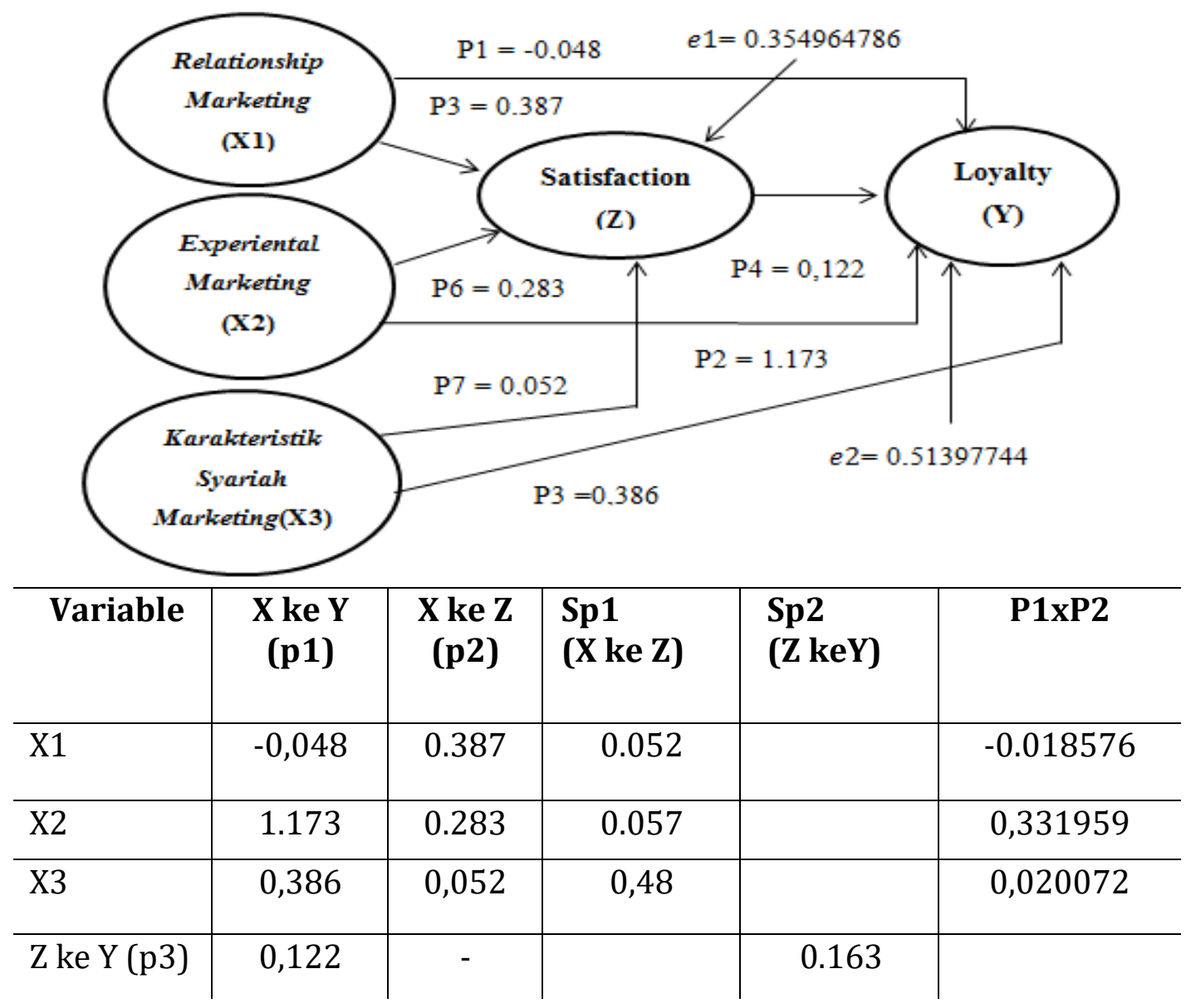




\subsection{Discussion}

\section{a) Relationship Marketing Relationships Affect Customer Loyalty}

The results of the first hypothesis test can be seen in table 2. Where the Relationship Marketing coefficient is -0.048 negative with a significance of $0.644>0.05$, meaning that Relationship Marketing (X1) has an insignificant negative effect on Customer Loyalty.

These results are different when compared simultaneously in the research of Synathra \& Sunarti, (2018) and Lollen Regina, (2019) which explain that the influence of Relationship Marketing is positive and significant on customer loyalty. The same results are only shown by research conducted by Karim et., (2020).

\section{b) The Effect of Experiential Marketing on Customer Loyalty}

The results of the second hypothesis test can be seen in table 2 . which states that the influence of Experiential Marketing is 0.173 positive and the significant value is $0.096<0.05$, meaning that the Effect of Experiential Marketing (X2) is positive but not significant on Customer Loyalty.

This conclusion agrees with Karuniatama et al., (2020) which states that there is a significant positive influence of Experiential Marketing on Loyalty. However, it is different as stated by Panjaitan, (2017) which concludes that the positive relationship is also significant.

c) The Effect of Sharia Marketing Characteristics on Customer Loyalty

The test results of the Characteristics of Sharia Marketing on Loyalty are described in table 2. Where the coefficient of the Characteristics of Sharia Marketing is 0.386 positive with a significant value of $0.00<0.05$, meaning that the influence of the Characteristics of Sharia Marketing (X3) is significant positive on Loyalty.

This conclusion is the same as research from Setiaji, (2019)which shows the influence of the variable characteristics of sharia marketing is positive and significant on loyalty. But it is not the same as Kurniawan research, (2019) which states that the effect is positive but not significant. Loyalty which is basically by maintaining sharia values in every banking economic activity, the increase in customer loyalty will be very rapid. It is undeniable that with the increase in sharia marketing, loyalty will increase because one of the causes of customers switching from conventional banking is the difference in terms of the points of sharia law.

d) Relationship of customer satisfaction in influencing customer loyalty

The results of the Satisfaction variable test on Loyalty can be seen in table 2. It is known that the Satisfaction coefficient of 0.122 is positive and its significance is $0.458<0.05$, meaning that the Effect of Customer Satisfaction (Z) is positive but not significant on Customer Loyalty.

This research can be seen in terms of how large the level of customer needs can be met, many cases occur with Islamic banking customers being more loyal to conventional banks because of various unmet needs when making transactions at Islamic banks. This is in line with previous research from Khamza (2018) and Muniroh (2017) which is different from the research of Nurhidayati \& Yuliantari (2018) which actually states that the relationship is negative and significant.

e) Relationship Marketing Relationships in Affecting Satisfaction 
These fifth results are described in table 2. Where the Relationship Marketing coefficient of 0.387 is positive and the significant level is $0.00<0.05$, meaning that the influence of Relationship Marketing (X1) is positive and significant on Customer Satisfaction (Z).

These results are in line with the opinion of a number of experts about the level of satisfaction of a customer, who describes that satisfaction can be perceived through expectations, a soul bond when making a purchase with the real performance of the product received in the transaction. So it can be interpreted that the level of customer satisfaction is directly proportional to how much customer trust is one indicator of Relationship Marketing to a company. Wicaksono (2018) and Santoso \& Japarianto (2019) The existence of Relationship Marketing is very influential in increasing the level of satisfaction.

f) The Relationship of Experiential Marketing in Influencing Satisfaction

This sixth test can be seen in table 2. Where the coefficient of Experiential Marketing is 0.283 positive with a significance level of $0.00<0.05$, meaning that the effect of Experiential Marketing (X2) is positive which is significant on Customer Satisfaction (Z).

These results are in line with Kertajaya's opinion that Experiential Marketing is a marketing scheme with the aim of creating loyal customers by touching their emotions in the form of emotional processing in the form of positive experiences felt by customers. In this case we can draw that Experiential Marketing actually has an influence on customer satisfaction. Rosita (2015) and Febrini et al., (2019) The significant positive effect of experiential marketing on customer satisfaction.

g) The Relationship between the Characteristics of Sharia Marketing in Affecting Satisfaction

The results of the seventh hypothesis test can be seen in table 2 . Where the Experiential Marketing coefficient is 0.052 positive with a significance level of $0.281<0.05$, meaning that the Ease Effect (X3) is positive but not significant on Customer Satisfaction (Z).

This agrees with Gusti (2019) and research conducted by Maulida et al., (2017), that the Characteristics of Sharia Marketing is a strategic business discipline which in every marketing model and transaction leads to Islamic principles, but in this case it cannot be can directly affect the level of satisfaction because other media are needed to be able to really feel the existence of excellent service, the ability to meet customer needs and so on.

h) The Effect of Satisfaction in Mediating Relationship Marketing Relationships on Loyalty

From the data processed by the author, it is known that the value of $t$ count is $-0.075248<\mathrm{t}$ table 1.98497 ( $\mathrm{t}$ table $=\mathrm{n}-\mathrm{k}=100-3=97$ at $\mathrm{a}$ significance of 0.05). From this comparison, it is known that t count is smaller than $\mathrm{t}$ table, which is significant. It means that Customer Satisfaction (Z) is not able to mediate Relationship Marketing on Loyalty. As the results of research from Widjaja (2016) In this case customer satisfaction is also not the only thing that can affect customer relationships with banks, one of which is because of the close relationship between banks and customers, the relationship in question is an emotional relationship that exists not only on the problem of satisfaction even though Pranomo et al., (2016) stated that it can mediate. 


\section{i) The Effect of Customer Satisfaction in Mediating Experiential Marketing Relationships on Loyalty}

From the data processed by the author, it is known that the t count value is $3.008550>\mathrm{t}$ table 1.98397 ( $\mathrm{t}$ table $=\mathrm{n}-\mathrm{k}=100-3=97$ at a significance of 0.05). From this comparison, it is known that $t$ count $>t$ table which is significant. This means that satisfaction is able to mediate Experiential Marketing on Loyalty which is basically the emotional feelings felt by customers can also increase if the initial expectations are in accordance with reality or are able to satisfy which makes customers loyal, this is in line with research by Fauzi (2019) and Amrullah (2017).

j) The Influence of Customer Satisfaction in Mediating the Relationship between Shariah Marketing Characteristics on Loyalty

From the data processed by the author, it is known that the value of $t$ count is $2.15849>\mathrm{t}$ table 1.98397. From this comparison, it is known that $\mathrm{t}$ count $>t$ table is significant. This means that Satisfaction $(\mathrm{Z})$ is able to mediate the influence of Sharia Marketing Characteristics (X3) on Loyalty (Y). The suitability of principles in terms of sharia is very risky to review, but with the level where customers are satisfied with what they expect, of course the level of customer loyalty will increase as well, the results of this study are in line with research conducted by Setiaji (2019) and Indriyantono, ( 2018).

\section{CLOSING}

\section{a. Conclusion}

This study found that the variables of Relationship marketing, Experiential marketing, and satisfaction did not have a positive and significant effect on customer loyalty, only the characteristics of sharia marketing variables that could directly affect customer loyalty. Then on the contrary, the characteristics of sharia marketing variables are not able to directly affect satisfaction while the other variables can. For the purpose of knowing the relationship of satisfaction variables in influencing X1, X2, X3 on loyalty, it can only affect experiential marketing variables and also the characteristics of sharia marketing, while for relationship marketing the satisfaction variable cannot mediate directly.

\section{b. Suggestion}

\section{For the next Researcher}

It is intended for further research so that researchers are better able to analyze what factors are able to influence customer loyalty, add variations to independent variables, add samples, can also add different methods to get better results.

\section{For sharia banking customers in the city of Salatiga}

It is expected to be able to analyze the form of Relationship Marketing, Experiential Marketing, Characteristics of Sharia Marketing, so that the process of establishing a good relationship with the company. Also able to grow trust in fulfilling their every need so that they can increase the use of Sharia banking services in the city of Salatiga from time to time which grows from a form of satisfaction that makes loyalty in using Sharia banking products. 


\section{REFERENCES}

Dewi, R. K., Kumadji, S., \& Mawardi, M. K. (2015). Pengaruh Experiential Marketing Terhadap Kepuasan Pelanggan Dan Dampaknya Pada Loyalitas Pelanggan. Jurnal Administrasi Bisnis, 28(1), 1-6.

Eka Yudiana, F., \& Setyono, J. (n.d.). Analisis Corporate Social Responsibility,Loyalitas Nasabah, Corporate Image dan Kepuasan Nasabah Pada Perbankan Syariah. 10(1), 93-114.

Fatmawati, R. D., \& Rahayu, Y. S. (2018). Seminar Nasional dan Call for Paper: Manajemen, Akuntansi dan Perbankkan 2018 | 1090. Seminar Nasional Dan Call for Paper: Manajemen, Akuntansi Dan Perbankkan 2018, 74-90.

Gusti, P. D. W. (2019). Pengaruh karakteristik syariah marketing terhadap kepuasan peserta di PT. Asuransi Takaful Keluarga Surabaya. 103. http://digilib.uinsby.ac.id/31495/

Karim, D., Sepang, J. L., Soepeno, D., \& Sepang, J. L. (2020). Pengaruh Relationship Marketing Dan Suasana Kafe Terhadap Loyalitas Pelanggan Di Rumah Kopi Billy Kawasan Megamas. Jurnal EMBA: Jurnal Riset Ekonomi, Manajemen, Bisnis Dan Akuntansi, 8(1). https://doi.org/10.35794/emba.v8i1.27361

Kartajaya, H., \& Sula, M. S. (2006). Syariah Marketing (0 ed.). Mizan.

Karuniatama, I. H., Barata, D. D., \& Suyoto, Y. T. (2020). Pengaruh Experiential Marketing Terhadap Loyalitas Pelanggan Ritel Di Indonesia. Widyakala: Journal $\begin{array}{llll}\text { of Pembangunan Jaya University, } & 7(1),\end{array}$ https://doi.org/10.36262/widyakala.v7i1.277

Khamza, K. P. (2018). Konsumen Pengguna Kereta Api ( Studi Kasus Pada Penumpang Kereta Api Kaligung ). Universitas Muhammadiyah Semarang.

Kurniawan, bayu aji. (2019). Pengaruh Social Media Promotion Relationship Marketing dan Karakteristik Syariah Marketing Terhadap Loyalitas Nasabah Dengan Kepuasan Nasabah Sebagai Variabel Intervening.

Lollen Regina, E. (2019). Pengaruh Relationship Marketing Terhadap Kepuasan Pelanggan Dan Loyalitas Pelanggan Koran Kompas Di Surabaya. Journal of Chemical Information and Modeling, 53(9), 1689-1699.

Manengkey, V. M., Tumbel, T. M., \& Kalangi, J. A. F. (2019). Pengaruh Experiental Marketing Terhadap Loyalitas Pelanggan Kebun Strawberry D'MO0AT. Jurnal Administrasi Bisnis, 9(1), 64. https://doi.org/10.35797/jab.9.1.2019.23558.6471

Panjaitan, D. . (2017). Pengaruh Experiential Marketing Terhadap Loyalitas Konsumen yang Dimediasi Variabel Kepuasan Konsumen (Studi Kasus: Fitness First Cabang Oakwood). Jurnal Online Internasional \& Nasional Universitas 17 Agustus 1945 Jakarta, 4(1), 44-60.

Prihanti, D. (2019). Pengaruh E-Service Quality, Islamic Branding Dan Islamic Advertising Ethics Terhadap Keputusan Pembelian (Studi Kasus pada Konsumen Shopee di Indonesia). IAIN Salatiga.

Putri, S., \& Nursinta, L. (2017). Pengaruh Relationship Marketing Terhadap Loyalitas Pelanggan Pada Konsumen Tropicana Slim di Kota Padang. Agribisnis Summatera Utara, 10(1), 13-21.

Rosita, N. P. S. (2015). Pengaruh Experiential Marketing Terhadap Kepuasan Pelanggan Swalayan Sinar Rahayu Negara Tahun 2014. Vol: 5(2), 11.

Setiaji, F. (2019). Pengaruh Karakteristik Syariah Marketing, Relationship Marketing Terhadap Loyalitas Nasabah dengan Kepuasan Nasabah Sebagai Variabel 
Intervening (Studi Kasus Paada BRI Syariah KCP Ungaran). IAIN Salatiga.

Synathra, V., \& Sunarti. (2018). Pengaruh Relationship Marketing Terhadap Kepuasan Nasabah dan Dampaknya Pada Loyalitas Nasabah (Survei pada Nasabah Tabungan BCA Kantor Kas Sawojajar Kota Malang). Jurnal Administrasi Bisnis (JAB), 55(1), 115-124.

Wicaksono, A. (2018). Pengaruh Relationship Marketing Terhadap Kepuasan Nasabah dalam Perspektif Ekonomi Islam (Studi Pada BTM BiMU Muhammadiyah, Bandar Lampung). In The Marketing Book. https://doi.org/10.4324/9780429203916-25 